NBER WORKING PAPER SERIES

\title{
DO CURRENCY MARKETS ABSORB NEWS QUICKLY?
}

\author{
Martin D.D. Evans \\ Richard K. Lyons \\ Working Paper 11041 \\ http://www.nber.org/papers/w11041
NATIONAL BUREAU OF ECONOMIC RESEARCH
1050 Massachusetts Avenue
Cambridge, MA 02138
January 2005

Respective affiliations are Georgetown University and NBER, and UC Berkeley and NBER. We thank the following for helpful comments: Carol Osler, Michael Melvin, and seminar participants at the 8th International Conference on Macroeconomic Analysis and International Finance. Both authors thank the National Science Foundation for financial assistance, which includes funding for a web clearinghouse for micro-based FX research (at faculty.haas.berkeley.edu/lyons, and at faculty.georgetown.edu/evans). The views expressed herein are those of the author(s) and do not necessarily reflect the views of the National Bureau of Economic Research.

(C) 2005 by Martin D.D. Evans and Richard K. Lyons. All rights reserved. Short sections of text, not to exceed two paragraphs, may be quoted without explicit permission provided that full credit, including () notice, is given to the source. 
Do Currency Markets Absorb News Quickly?

Martin D.D. Evans and Richard K. Lyons

NBER Working Paper No. 11041

January 2005

JEL No. F3, F4, G1

\title{
ABSTRACT
}

This paper addresses whether macro news arrivals affect currency markets over time. The null from macro exchange-rate theory is that they do not: macro news is impounded in ex-change rates instantaneously. We test this by examining the effects of news on subsequent trades by end-user participants (such as hedge funds, mutual funds, and non-financial corpo-rations). News arrivals induce subsequent changes in trading in all of the major end-user segments. These induced changes remain significant for days. Induced trades also have per-sistent effects on prices. Currency markets are not responding to news instantaneously.

\author{
Martin D. D. Evans \\ Georgetown University \\ Department of Economics \\ Washington DC 20057 \\ and NBER \\ evansm1@georgetown.edu \\ Richard K. Lyons \\ U.C. Berkeley \\ Haas School of Business \\ Berkeley, CA 94720-1900 \\ and NBER \\ lyons@haas.berkeley.edu
}




\section{Do Currency Markets Absorb News Quickly?}

This paper addresses an important null hypothesis within exchange-rate theory: that macro news is impounded in exchange rates instantaneously. This is typically understood to mean a matter of seconds, or perhaps minutes (e.g., 5 to 10), but certainly contained within the day of news arrival. We test this by examining the effects of news on subsequent currency trades by enduser participants (such as hedge funds, mutual funds, and non-financial corporations). We find that news arrivals induce subsequent changes in trading behavior in all of these major end-user segments. These induced changes in trading remain significant for days. Induced trades also have persistent effects on prices. These findings provide strong evidence that currency markets are not responding to news instantaneously.

Our basis for pursuing whether induced trades might prolong the absorption of news comes from recent empirical work demonstrating a tight link between signed transaction volume (order flow) and signed exchange rate changes. ${ }^{1}$ This link is not predicted by macro exchange rate theory, but it is predicted by an alternative modeling framework from microstructure finance. In this micro-based framework, transactions play a central, causal role in price determination (see, e.g., Glosten and Milgrom 1985, Kyle 1985). The causal role arises because transactions convey information that is not common knowledge. In this paper, we address whether the tight link between price adjustment and order flow that exists in general might also be playing a role in how currency markets absorb news.

Most of the existing literature linking exchange rates to news is event-study based, and does not address how transaction quantities respond to news (i.e., it addresses the link between news and price in isolation). This literature has two branches. The first addresses the direction of exchange-rate changes (first moments) and the second, later branch addresses exchange-rate volatility (second moments). A common finding of the first branch is that, at least at the daily frequency, directional effects from scheduled macro announcements are difficult to detect because they are swamped by other factors affecting price. Intraday event studies do find statistically significant effects, particularly for employment and money-supply announcements

\footnotetext{
1 This evidence is from both micro (i.e., single marketmaker) and macro (marketwide) studies. On the micro side, see, e.g., Lyons (1995) and Bjonnes and Rime (2004). On the macro side, see, e.g., Evans and Lyons (2002a,b), Payne (2003), Osler (2004), and Bjonnes, Rime, and Solheim (2004). Order flow is the cumulation over time of signed trades, where trades are signed according to whether the initiating side is buying or selling. (The marketmaker posting the quote is the non-initiating side.)
} 
(Andersen et al. 2003). ${ }^{2}$ The second, later branch of this literature-which focuses on news effects on volatility - is partly a response to early difficulty in finding news effects on first moments. ${ }^{3}$ This work finds that arrival of scheduled announcements does indeed produce the largest exchange-rate changes. Nevertheless, the ability of these fundamentals to account for overall volatility changes is lower than that of less fundamental factors such as time-of-day effects and ARCH (Andersen and Bollerslev 1998).

A more recent literature has emerged that addresses the currency market's response to news as a joint quantity/price response (Carlson 2002, Danielsson et al. 2003, Evans and Lyons 2003). Carlson (2002), for example, takes a case-study approach and analyzes a single macro announcement arrival. He finds that market characteristics were affected for hours following the arrival. (For example, liquidity remained significantly below normal-and below its ex ante state-for about 2 hours.) The case-study approach leaves open the question of how systematic these prolonged market effects are, and whether they might extend beyond the day of news arrival. The work of Danielsson et al. (2003) and Evans and Lyons (2003) provides less intraday resolution than Carlson, but these papers do examine multiple news arrivals over periods of months, and thereby do provide and sense for whether quantity responses to news are systematic. (Both papers find, for example, that roughly half of the transmission of news to prices actually operates through induced order flows.) Nevertheless, given sample sizes measured only in months, both of these papers have to aggregate across arrivals of very different news types. The limited sample sizes also restrict them to examining only induced transaction effects intradayneither paper addresses whether the absorption of news is prolonged over more extended periods.

Our paper departs from earlier work in three main ways. First, our analysis is based on the induced trades of currency-market end users. All three of the papers noted in the previous paragraph use quantity data that reflects trades between marketmakers only (i.e., interbank trades). ${ }^{4}$ This is relevant for the question that we address because, relative to end users, marketmaker reactions to news are unlikely to be as protracted. Second, our data span over 6 years, a much longer sample than is used in existing work on the joint quantity/price response to news. This allows us to treat individual announcement types separately, without aggregating them into

\footnotetext{
${ }^{2}$ See also, for example, Cornell (1982), Engel and Frankel (1984), Hakkio and Pearce (1985), Ito and Roley (1987), Hardouvelis (1988), Klein (1991), and Ederington and Lee (1995).

${ }^{3}$ See, for example, Goodhart et al. (1993), DeGennaro and Shrieves (1997), and Andersen and Bollerslev (1998). See also the work on bond prices and announcements, e.g., Fleming and Remolona (1999), Balduzzi et al. (2001), Fleming (2002), and Green (2002). The latter two papers are especially relevant in that they use direct measures of order flow in fixed income markets. Green (2002), for example, finds evidence that asymmetric information increases following public macro announcements.
} 
composite news measures. We find, in fact, that different announcement types have quite different effects on induced transactions, which is consistent with the findings of earlier work that addresses the news/price link in isolation. Third, and also related to the sample length, we are able to address whether the market's absorption of news is genuinely protracted, which here we take to mean that it extends beyond the intraday dynamics addresses elsewhere.

The remainder of the paper is in four sections. Section 1 describes our data and presents descriptive statistics. Section 2 addresses identification, specifically, our approach to identifying effects of news on trades and prices. Section 3 presents our analysis of how news affects trades and prices beyond the arrival day. Section 4 concludes.

\section{Data and Descriptive Statistics}

This paper uses transaction data on end-user customers, which is a qualitative departure from other micro-approach analysis of exchange rates and news. These data are from Citibank and cover all of the customer trades that Citibank executed in the USD/EUR market from April 11, 1993 to June 30, 1999. (Prior to the euro's launch in January, 1999, these trades correspond to the trades of all the euro component currencies against the USD.) Citibank is among the top three currency marketmakers worldwide, with a market share for end-user customers around 10 percent (major currencies against the dollar). These transactions data are daily aggregatesintraday data were not available to us. (Any trades with end-users that are executed over a weekend - relatively rare - are included in Monday order flows, so each trading week has five days.) Days begin in this dataset at 00:00 GMT. This timing applies to both the end-user transactions and to the daily log exchange rate changes (the latter also from Citibank). Henceforth, we shall refer to daily log exchange rate changes as "returns". (Prior to the Euro's launch, exchange rates for the euro against the dollar are synthesized from the underlying bilateral rates against the dollar, using the respective weights in the euro.)

Advantages of the data are many. First, the data span more that six years, so analysis of announcements that arrive only monthly is possible. Second, the data include both spot and forward trades, but are netted of any trades in FX swaps (because FX swaps do not have net order flow implications - they correspond to offsetting purchases and sales). Third, and perhaps most

\footnotetext{
${ }^{4}$ Moreover, these other micro-approach papers consider only aggregate trade processes, whereas we analyze end-user trades at a disaggregated level, i.e., six different segments.

${ }^{5}$ Osler (2002) also obtains data on FX customer trades directly from a private bank. Her focus is stop-loss and takeprofit orders. She shows that clustering of these orders at particular prices helps to explain two familiar predictions from technical analysis, namely that (1) trends tend to be reversed at support and resistance levels and (2) trends tend to gain momentum if support and resistance levels are breached.
} 
importantly, the data are split into three customer-type categories: non-financial corporationshenceforth "Corporations", unleveraged financial institutions (e.g., mutual funds)-henceforth "Investors", and leveraged financial institutions (e.g., hedge funds)-henceforth "Traders". ${ }^{6}$ At Citibank over this period, the total end-user trading volume in USD/EUR across the three categories is roughly equal (for additional detail on relative volumes across segments in these data, see Lyons 2001). In addition to the three-segment breakdown by participant type, the dataset also distinguishes customer trades that were executed with Citibank's US-based marketmakers versus those executed elsewhere within Citibank's global trading operation (referred to as "nonUS"). Thus, the end-user transactions are partitioned into six non-overlapping segments, corresponding to three participant types times two trade locations.

Our announcement data are from International Money Market Services (MMS). These include real-time data on both expected and announced macro variables, from which we construct time series of macro news. Our sample includes 30 US and 13 German scheduled announcements. (For a list, see the second column of Table 2.) The expectation for each announcement is based on the median response from a survey of approximately forty money managers on the Friday of the week before the announcement. These data have been used in many earlier studies (see, for example, Urich and Watchel 1984, Balduzzi et al. 2001, and Andersen et al. 2003). We follow this literature by constructing for each announcement a time series of standardized news. Specifically, the standardized news in announcement $i$ on day $t$ is:

$$
n_{i, t}=\frac{V_{i, t}-E_{i, t}}{\hat{\sigma}_{i}}
$$

where $V_{i, t}$ is the value announced for variable $i, E_{i, t}$ is the survey expectation of $V_{i, t}$, and $\hat{\sigma}_{i}$ is the sample standard deviation of $V_{i, t}-E_{i, t}$ across announcement days $t .^{7}$ Both US and German announcements are made on fixed days, so the daily timing of each announcement is known in advance. We set $n_{i, t}=0$ on days for which no announcement is scheduled.

\footnotetext{
${ }^{6}$ A natural question is where the trades of central banks appear. The source of these data is reluctant to disclose the specifics. Though not addressed here, the source bank does maintain a fourth category of customer called "miscellaneous." This fourth category is likely to include any central bank trades for which the source bank was the counterparty. (Trading volume within this fourth category is quite small relative to volume in the three main categories, consistent with the fact that central bank trades in the USD/EUR market were quite small over this period relative to private trades.)

7 The Fed Funds Rate is one of our news items. Announcements about Fed Funds come from the series constructed by Brandt et al. (2001), kindly provided by Kenneth Kavajecz. Expectations for the Funds rate come from the MMS survey.
} 
Though the daily frequency of our transaction data do not permit intraday analysis, there is an important advantage to daily analysis that deserves note. Daily data provide a solid indication of price effects at lower frequencies (i.e., those more familiar to macroeconomists, such as monthly) because the daily frequency is the highest at which the nominal exchange rate can be reliably described as a martingale. Any empirical model that explains daily price increments is therefore relevant for explaining exchange rate levels at long horizons (i.e., one cannot sensibly argue that daily price movements are rapidly dissipating). This martingale property at the daily frequency does not apply to intraday prices, which exhibit mean reversion (see, e.g., Evans 2002).

\section{Descriptive Statistics}

Table 1 presents descriptive statistics for the main variables that we model below, specifically, the daily exchange rate return, the aggregate daily end-user order flow, and the six disaggregated end-user order-flow segments. $\Delta p_{t}$ denotes the difference between the log spot rate $(\$ / €)$ at the end of days $t$ and $t-1$, and $\Delta x_{t}^{j}$ denotes the order flow for euros from segment $j$ during day $t$. Note from row 1 that there is no evidence of unconditional serial correlation in daily FX returns ( $p$-values in parentheses). This means that if news is to have prolonged effects on prices, it must come from conditioning on order flows. In contrast, there is evidence of autocorrelation in the order flow segments; the autocorrelation coefficients are small, but many are highly statistically significant. From the correlation matrix, we see that order flow segments are not particularly strongly correlated among themselves at the daily frequency. But order flows are strongly correlated with returns (less so, however, than interdealer data; see Evans and Lyons 2002a).

Figure 1 provides complimentary evidence on the relation between the different order flow segments. Panel A shows that order flows executed at US and non-US locations diverge quite significantly in the last two years of the sample. The origins of this divergence can be seen in Panels B-D. Corporate order flows for the euro have been generally negative, but much more so at non-US than US locations. By contrast, Investor order flows were generally positive, but the rise in order flow from non-US Investors led US Investors by several years. (We shall refer to investor flow executed outside the US as coming from non-US Investors, though strictly speaking, we cannot distinguish the location of the Investor from the location of the trade execution; similarly for the other segments.) Order flow originating from US and non-US Traders diverge sharply after 1995 . The message conveyed by Figure 1 is that the low daily correlations 
between the different order-flow segments reported in Table 1 translate into sizable cumulative differences over months and years.

\section{Identifying News Effects on Trades and Prices}

One can think of the information in news as having two components. The first component is a common-knowledge (or "mean") part: all agents agree about the appropriate impact of this first part on the exchange rate. In macro models of news in currency markets, this first part is the whole story: it fully characterizes the instantaneous adjustment of exchange rates to news. The second component is the part whose implication for the exchange rate is not common knowledge. It is this second part that is impounded in exchange rates via induced trading. Suppose, for example, that all agents do not have access to the same technology for transforming the macro data into an exchange rate forecast. The resulting inferences drawn are not known by the marketmakers a priori. How do marketmakers aggregate the information in these inferences? The answer from microstructure theory is that they learn from the sequence of submitted orders over time. In this case, price adjusts instantaneously to the marketmaker's rational expectation of the market's interpretation (this is the first of the two components), and then goes through a period of gradual adjustment caused by the sequence of transacted orders. ${ }^{8}$

With respect to response time, remember that the announcements that we address here are scheduled, so participants can plan their responses (conditional on realizations) in advance. This is likely to lower response lags considerably relative to unscheduled news. In this sense, our tests for whether market responses to news are protracted are conservative tests. Note, too, that the model that we present below is capturing average responses (i.e., the total average response, including the induced order flow effects). This is distinct from second-moment effects, i.e., effects on volatility. In fact, in response to news, order flow and price are also (jointly) more volatile, which adds a dimension to the first-moment analysis that we do here. Addressing directly these second-moment effects would take us too far afield from our central question, so we do not take it on within this paper.

\section{The Empirical Model}

Our aim is to study the impact of news announcements on spot rates and order flows in

\footnotetext{
${ }^{8}$ From our observations of how the FX market absorbs macro news in practice, some price adjustment by marketmakers does indeed occur rapidly, though generally not a lot, and this initial adjustment involves little apparent role for flow. But informal observation also makes it clear that news regularly induces follow-on trading by end-user customers, whose trading responses are not instantaneous.
} 
the days following the announcement. For this purpose, we model the daily dynamics of prices and order flows as a 7-variable, $\mathrm{k}^{\text {th }}$-order VAR:

$$
\left[\begin{array}{c}
\Delta p_{t} \\
\Delta x_{t}^{1} \\
\vdots \\
\Delta x_{t}^{6}
\end{array}\right]=A_{1}\left[\begin{array}{c}
\Delta p_{t-1} \\
\Delta x_{t-1}^{1} \\
\vdots \\
\Delta x_{t-1}^{6}
\end{array}\right]+A_{2}\left[\begin{array}{c}
\Delta p_{t-2} \\
\Delta x_{t-2}^{1} \\
\vdots \\
\Delta x_{t-2}^{6}
\end{array}\right]+\ldots+A_{k}\left[\begin{array}{c}
\Delta p_{t-k} \\
\Delta x_{t-k}^{1} \\
\vdots \\
\Delta x_{t-k}^{6}
\end{array}\right]+\left[\begin{array}{c}
e_{t} \\
u_{t}^{1} \\
\vdots \\
u_{t}^{6}
\end{array}\right],
$$

where $\Delta p_{t}$ denotes the difference between the log spot rate $(\$ / €)$ at the end of days $t$ and $t-1$, and $\Delta x_{t}^{j}$ denotes the order flow for euros from segment $j$ during day $t$. Daily innovations to the spot rate and the 6 order flows are denoted by $e_{t}$ and $u_{t}^{j}$, respectively. These innovations are driven, in part, by macro announcements according to:

$$
\begin{aligned}
& e_{t}=\sum_{i=1}^{M} \beta_{i} n_{i, t}+\xi_{t}, \\
& u_{t}^{j}=\sum_{i=1}^{M} \beta_{i}^{j} n_{i, t}+\zeta_{t}^{j} \quad j=1,2, \ldots 6,
\end{aligned}
$$

where $M$ is the number of announcement types (43 in our case) and $n_{i, t}$ is the standardized news arising from announcement $i$ on day $t$. The $\xi_{t}$ and $\zeta_{t}^{j}$ shocks represent the sources of spot rate and order flow innovations that are uncorrelated with the news announcements. These shocks may be correlated. For example, shocks to order flow during the day may lead marketmakers to revise their quoted prices. Alternatively, unexpected price movements during the day may induce a change in order flow (via feedback trading). Our model does not restrict the correlation between the $\xi_{t}$ and $\zeta_{t}^{j}$ shocks.

The effects of announcements are identified by the $\beta$ coefficients: $\beta$, identifies the effect of news in announcement $i$ on the log spot rate; while $\beta_{i}^{j}$ indicates how the news affects the $j^{\text {th }}$ order flow segment. Notice that none of the coefficients identify the intra-day transmission mechanism through which the spot rate and order flow changes take place. For example, news may affect the spot rate directly because it induces marketmakers to change their quotes. News may also affect spot rates because marketmakers change their quotes in response to induced order flow. Our model does not distinguish between this direct and indirect transmission channel (see Evans and Lyons 2003 for a model that does distinguish them). The $\beta_{t}$ coefficient simply identifies the total daily effect of the $i^{\text {th }}$ news item. Similarly, $\beta_{i}^{j}$ coefficient indicates the total daily effect of news on order flow. 
Our model enables us to focus on three issues: (i) If news affects order flow, do the effects persist beyond the day of the announcement? (ii) If news affects spot rates, are all the effects confined to the day of the announcement? (iii) Do news-induced order flows generate price movements after the announcement day?

All these questions can be readily addressed by computing impulse response functions. Specifically, we can trace out the impact of the news in announcement $i$ on the spot rate and order flows using the estimates of $\beta_{\imath}$ and $\beta_{i}^{j}$, together with the VAR coefficients in the $A_{k}$ matrices. For example, let $\left\{\hat{B}_{k}\right\}_{k=0}^{\infty}$ denote the sequence of matrices that define the vector moving average representation of the estimated VAR (with $\hat{B}_{0}=I$ ), and let $\hat{b}_{i}{ }^{\prime}=\left[\hat{\beta}_{i}, \hat{\beta}_{i}^{1}, \ldots \hat{\beta}_{i}^{6}\right]$ be the vector of estimated $\beta$ coefficients for the news in announcement $i$. The estimated impact of a one standard deviation news shock on the exchange rate return $k$ periods after the announcement is given by the first row of $\hat{B} \hat{b}_{i}$, while the impact on the $j^{\text {th }}$ order flow is given by row $j+1$ of $\hat{B} \hat{b}_{i}$.

To determine the statistical significance of our estimated impulse responses we conduct a series of Monte Carlo experiments. Each experiment imposes a particular null hypothesis on the $\beta$ coefficients used in generating pseudo data samples. Let $\hat{\beta}^{0}$ denote the matrix of estimated $\beta$ coefficients under the null (specified below). We compute Monte Carlo p-values under the null as follows: First we draw a sequence for $\left\{\tilde{\xi}_{t}, \tilde{\zeta}_{t}^{1} \ldots \tilde{\zeta}_{t}^{6}\right\}_{t=1}^{T}$ from $N(0, \hat{\Sigma})$, where $\hat{\Sigma}$ is the estimated covariance matrix of $\left\{\xi_{t}, \zeta_{t}^{1} \ldots \zeta_{t}^{6}\right\}$ and $T$ is the number of trading days in our sample. We then combine these pseudo shocks with the actual data on news and $\hat{\beta}^{0}$ to compute a set of VAR innovations under the null according to equations (3) and (4). From these innovations, we use equation (2) together with the estimates of the VAR coefficients in $A_{k}$ to generate a pseudo time series for $\Delta p_{t}$ and $\Delta x_{t}^{j}$ (the pre-sample estimates of $\Delta p_{t}$ and $\Delta x_{t}^{j}$ are set equal to zero). With this generated data, we next estimate the VAR and the $\beta$ coefficients with the null hypothesis imposed. From these estimates, we then compute the impulse response functions. The Monte Carlo distribution under the null is constructed from the empirical distribution of the impulse responses computed from 1000 pseudo data sets.

\section{News Effects on Trades and Prices Beyond the Arrival Day}

Our main results are presented in a series of five tables, Tables 2-6. Table 2 reports our estimates of the $\beta$ coefficients from the model in equations (2)-(4), i.e., the coefficients that determine the effects of news arrivals on innovations in our VAR. Table 3 describes the dynamics 
of segment order flows over the days following news arrival (in the form of impulse responses). Table 4 addresses the dynamics of segment order flows in a different way: it presents the variance of order flow due to news as a percentage of the order-flow variance due to all shocks. Tables 5 and 6 parallel Tables 3 and 4: they describes return dynamics, first as impulse responses (Table 5 ), and then in the form of the ratio of return variance due to news relative to return variance due to all shocks.

\section{Effects of News Arrivals on VAR Innovations}

Table 2 reports the estimates of the $\beta$ coefficients using innovations from a second-order VAR (where the order of the VAR was determined using the BIC information criterion). The column labeled \#N shows the number of announcements over the $6+$ year sample period. To interpret the "Returns" column, note that a positive shock of one standard deviation to non-farm employment (announcement 23) leads to a 24 basis point appreciation of the dollar (reduces the dollar price of a euro). Beyond non-farm employment, which is the biggest coefficient in the Return column, nine other news items have a significant impact on spot rates at the $5 \%$ level. Andersen et al. (2003) also find that news concerning non-farm employment has the largest impact of spot rates, but their intra-day estimate using a 5-minute sampling frequency is approximately half the size found here. (One possibility for this discrepancy is that our estimate also incorporates the impact on returns from news-generated order flows that occur the same day.) As a rule, more news items have significant effects on order flows than on returns. For example, news about non-farm employment has a large and statistically significant impact on order flow from US traders. To interpret these "Order Flow" columns, note that a positive shock of one standard deviation to non-farm employment induces sales of Euros (purchases of Dollars) equal to approximately $\$ 29 \mathrm{~m}$.

\section{Order Flow Dynamics Following News}

Table 3 describes the dynamics of segment order flows over the days following news arrival (in the form of impulse responses). Since there are 6 flow segments and 43 news items, we focus on those news items that have a significant impact (at the 5\% level) on order flow on the day of the announcement. For each news item meeting this criterion, the table reports the impulse response of the order flow registering the largest initial impact. The table also reports the p-value for the null hypothesis that the news item has no immediate impact on the order flow segment. These p-values are computed from the Monte Carlo experiments described above with the 
restriction that $\beta_{i}^{j}=0$ for all $i$ and $j$. (Note that while $\beta_{i}^{j}=0$ under this null, news can still affect order flows on the days following an announcement if the news affects spot rates and the effects feed through to order flow via some form of feedback trading.) In all but two cases (Fed funds news and Preliminary GDP news) news has a significant impact on order flow on at least one day following the announcements. In most cases, the cumulative effect of the news on order flow (shown in the last column) is also highly statistically significant. ${ }^{9}$

Table 4 addresses the dynamics of segment order flows in terms of the ratio of order-flow variance from news relative to order-flow variance from all shocks. Specifically, the table reports how news shocks contribute to the variance of segment order flows over five days, starting with the day of the announcement (i.e., one trading week). The set of news shocks and order flow segments that we present are the same as those in Table 3. Announcement news is a non-trivial source of daily variance in several of the order flow segments, particularly in the case of GDP and consumption expenditures. The prolonged effects of news on some of the flow segments shows up in the variance contributions $2-4$ days after the announcement. To summarize, the evidence in Tables 3 and 4 indicates that news does indeed affect order flows, and that the effects persist for several days beyond the day of the announcement.

\section{$\underline{\text { Return Dynamics Following News }}$}

Do the news-induced order flows affect price? This question is addressed in Tables 5 and 6. These two tables parallel Tables 3 and 4: they describes return dynamics, first as impulse responses (Table 5), and then in the form of the ratio of return variance due to news relative to return variance due to all shocks. Specifically, Table 5 addresses the question of whether the impact of news on returns persists beyond the day of the announcement. For perspective, recall from Table 1 that there is no evidence of unconditional serial correlation in $\Delta p_{t}$, so one would not expect to see any spot rate changes on days following announcements in the absence of order flow effects on returns. Granger causality tests (unreported) show that lagged values of $\Delta p_{t}$ have no forecasting power for subsequent $\Delta p_{t}$ (the p-value is 0.363 ). In contrast, order flows from US Traders and US Investors do have forecasting power for $\Delta p_{t}$ : the p-values are 0.002 and 0.079

\footnotetext{
9 These effects arise because order flows segments have forecasting power for other segments not because individual segments are strongly autocorrelated (See Table 1). Granger causality tests (unreported) show eight cases of statistically significant cross-segment Granger causality (i.e., order flow segment $j$ Granger causes order flow segment i).
} 
respectively. This raises the possibility that news can have persistent effects on returns beyond the day of the announcement via the long-lasting effects documented in Tables 3 and $4 .{ }^{10}$

Table 5 focuses on the return dynamics induced by those news items whose immediate impact is statistically significant at the $5 \%$ level. The table reports the impact of news on $\Delta p_{t}$ on the four days following the announcement (expressed as a percentage of the impact on the announcement day). Thus, negative numbers reflect subsequent reversal over the days following the initial news shock. For example, in the period following a positive shock of one standard deviation in unemployment claims, the euro depreciated by approximately $17 \%$ of the initial impact effect. The table also reports the p-value for the null hypothesis that the news item has no immediate impact on any order flow segment. As above, these p-values are computed from the Monte Carlo experiments with the restriction that $\beta_{i}^{j}=0$ for all $i$ and $j$. Under this null, news can only affect returns on the days after an announcement via its impact on spot rates on the announcement day.

The last column reports the cumulative response over the four days following the announcement. In every case where the cumulative response appears significant at the 5\% level, its sign is negative. This indicates that the prolonged absorption of news identified by the model tends to imply a systematic partial reversal of the initial price-impact. These reversals are largest in the case of US news concerning unemployment claims and the trade balance.

Table 6 reports how news contributes to the variance of daily returns over five days, starting with the day of the announcement. As above, we report variance decompositions only for the shocks studied in the spot rate impulse response functions. News about non-farm employment makes a far larger contribution to the variance of daily returns on the day of the announcement than news about the other items. Innovations to spot prices from all sources do not make a sizable contribution to the variance of returns on the days that follow. (Recall from Table 1 that there is little serial correlation in $\Delta p_{t}$.) However, insofar as they make some contribution, news shocks account for a sizable fraction.

\section{Conclusions}

This paper extends the literature on exchange rates and news in three main ways. First, no other paper has addressed news using the trades of end-user customers. Indeed, most papers in this area do not consider that prices and quantities are joint processes (i.e., they address the link

\footnotetext{
10 This is not a violation of standard definitions of market efficiency: the market at a whole cannot condition on these
} Citibank data - they are proprietary. 
between news and price in isolation). Recent papers that do address these joint dynamics focus exclusively on trades between marketmakers-i.e., interbank trades - rather than on trades of end users (Carlson 2002, Danielsson, Love, and Payne 2003, Evans and Lyons 2003). ${ }^{11}$ This is relevant for the question that we address because, relative to end users, marketmaker reactions to news are unlikely to be as protracted. Second, on the methodological front, we introduce a novel identification approach for isolating news shocks and their effects on trades and prices (specifically, our projection of the VAR innovations on news shocks). Third, our results provide forceful evidence that currency markets are still absorbing news after several days. By "still absorbing" we mean that end-user trades are still being induced, and these induced trades are having persistent effects on prices.

To understand how the market impact of news can be protracted, it is helpful to distinguish average news effects from total news effects. Average effects correspond to the direct (or "rational-expectations") channel for price impact, which one would expect to be reflected immediately, i.e., more quickly than indirect, order-flow-driven effects. Even if average effects from news are reflected in prices quickly, as found many past papers (e.g., Andersen and Bollerslev 1998 and Cheung and Chinn 2001), this does not imply that total effects are reflected quickly. Rather, participants' macro views evolve continually, and trades induced by those evolving views hit the market over extended periods. (Think, for example, of a mutual fund or corporate treasury group that has a currency "strategy meeting" only, say, once per week.) This idea links rather naturally to the analysis in Andersen et al. (2003): they find that the impact effect of announcements - the average signed effect on price - is absorbed quite quickly, whereas the initial effect on volatility is only partial, rising over time (and hour or more) and only later decaying.

What implications can be drawn from these results? First, the event-study approach to measuring news effects, which is employed by virtually every paper in this large literature, does not appear well-suited to capturing the total effect of news, given the protracted market absorption identified here. This under-estimate of total effects may be linked to what is arguably the central puzzle in this literature - the puzzle of missing news effects, i.e., that past measures of average news effects can account for only around 3 percent of total exchange rate variation (Evans and Lyons 2003). Second, prices are affected by these protracted, news-related trades, suggesting that markets are not treating them as inconsequential. (Put differently, the market is

\footnotetext{
${ }^{11}$ Moreover, these other micro-approach papers consider only aggregate trades processes, whereas we analyze enduser trades at a disaggregated level, i.e., six different segments.
} 
not identifying these induced trades as pure "animal spirits" and willingly taking the other side at existing prices.) Third, we cannot rule out the possibility that the induced trades are in fact nonrational. If the market as a whole is not large enough to absorb non-rational trades at existing prices, or if the market cannot distinguish them from other trades that convey information, then prices can be affected, despite the lack of any macro information content. Further work will be needed to distinguish this non-rational interpretation from other possibilities. From our perspective, there are in fact three main hypotheses that further work will need to discriminate: (1) newsinduced trades are rational and convey incremental information about the true state of the macroeconomy; (2) news-induced trades are rational, but are motivated by risk management-e.g., portfolio rebalancing - rather than macro information; and (3) news-induced trades are nonrational in some way, perhaps corresponding to the distinct cognitive biases identified within behavioral finance. Distinguishing among these three hypotheses is an important frontier for micro-based research on exchange rates. 


\section{References}

Andersen, T., and T. Bollerslev (1998), Deutsche mark-dollar volatility: Intraday activity patterns, macroeconomic announcements, and longer run dependencies, Journal of $\mathrm{Fi}$ nance, 53: 219-265.

Andersen, T., T. Bollerslev, F. Diebold, C. Vega (2003), Micro effects of macro announcements: Real-time price discovery in foreign exchange, American Economic Review, 93: 38-62.

Balduzzi, P., E. Elton, and C. Green (2001), Economic news and bond prices, Journal of Financial and Quantitative Analysis, forthcoming.

Berry, T., and K. Howe (1994), Public information arrival, Journal of Finance, 49: 1331-1346.

Bjonnes, G., and D. Rime (2004), Dealer behavior and trading systems in the foreign exchange market, Journal of Financial Economics, forthcoming.

Bjonnes, G., D. Rime, and H. Solheim (2004), Liquidity provision in the overnight foreign exchange market, Journal of International Money and Finance, this issue.

Brandt, M.W., Edelen, R. and Kavajecz, K.A. (2001), "Liquidity in the US Treasury Market: Asymmetric Information and Inventory Effects," Manuscript, Department of Finance, The Wharton School, University of Pennsylvania.

Carlson, J. (2002), One minute in the life of the DM/\$: Public information in an electronic market, typescript, Purdue University, August.

Cheung, Y., and M. Chinn (2001), Currency traders and exchange rate dynamics: A survey of the U.S. market, Journal of International Money and Finance, 20: 439-471.

Cornell, B. (1982), Money supply announcements, interest rates, and foreign exchange, Journal of International Money and Finance, 1: 201-208.

DeGennaro, R., and R. Shrieves (1997), Public information releases, private information arrival, and volatility in the foreign exchange market, Journal of Empirical Finance, 4: 295-315.

Eddelbuttel, D., and T. McCurdy (1998), The impact of news on foreign exchange rates: Evidence from high frequency data, typescript, University of Toronto.

Ederington, L., and J. Lee (1995), The short-run dynamics of price adjustment to new information, Journal of Financial and Quantitative Analysis, 30: 117-134.

Evans, M. (2002), FX trading and exchange rate dynamics, Journal of Finance, 57: 2405-2448.

Evans, M., and R. Lyons (2002a), Order flow and exchange rate dynamics, Journal of Political Economy, 110: 170-180.

Evans, M., and R. Lyons (2002b), Informational integration and FX trading, Journal of International Money and Finance, 21: 807-831.

Evans, M., and R. Lyons (2003), How is macro news transmitted to exchange rates? NBER Working Paper 9433, January (at faculty.haas.berkeley.edu/lyons).

Fleming, M., (2002), Price discovery in the U.S. treasury market: The impact of order flow and liquidity on the yield curve, typescript, New York Federal Reserve Bank, September.

Fleming, M., and E. Remolona (1999), Price formation and liquidity in the U.S. treasury market, Journal of Finance, 54: 1901-1915.

Glosten, L., and P. Milgrom (1985), Bid, ask, and transaction prices in a specialist market with heterogeneously informed agents, Journal of Financial Economics, 14: 71-100.

Goodhart, C., S. Hall, S. Henry, and B. Pesaran (1993), News effects in a high-frequency model of the sterling-dollar exchange rate, Journal of Applied Econometrics, 8: 1-13.

Green, C., (2002), Economic news and the impact of trading on bond prices, typescript, Emory University, May, Journal of Finance, forthcoming.

Hakkio C., and D. Pearce (1985), The reaction of exchange rates to economic news, Economic Inquiry, 23: 621-635.

Hardouvelis, G. (1988), Economic news, exchange rates, and interest rates, Journal of International Money and Finance, 7: 23-25. 
Hasbrouck, J. (1991), Measuring the information content of stock trades, Journal of Finance, 46: 179-207.

Ito, T., and V. Roley (1987), News from the U.S. and Japan: Which moves the yen/dollar exchange rate? Journal of Monetary Economics, 19: 255-277.

Kandel, E., and N. Pearson (1995), Differential interpretation of public signals and trade in speculative markets, Journal of Political Economy, 103: 831-872.

Klein, M. (1991), Managing the dollar: Has the Plaza Agreement mattered? Journal of Money, Credit, and Banking, 23: 742-751.

Kyle, A. (1985), Continuous auctions and insider trading, Econometrica, 53:1315-35.

Lyons, R. (1995), Tests of microstructural hypotheses in the foreign exchange market, Journal of Financial Economics, 39: 321-351.

Lyons, R. (2001), The Microstructure Approach to Exchange Rates, MIT Press, (chapters at faculty.haas.berkeley.edu/lyons).

Melvin, M., and X. Yin (2000), Public information arrival, exchange rate volatility, and quote frequency, Economic Journal, 110: 644-661.

Osler, C. (2002), Currency orders and exchange-rate dynamics: An explanation for the predictive success of technical analysis, Journal of Finance, forthcoming.

Osler, C. (2004), Stop-loss orders and price cascades in currency markets, Journal of International Money and Finance, this issue.

Payne, R. (2003), Informed trade in spot foreign exchange markets: An empirical analysis, Journal of International Economics, 61: 307-329.

Urich, T., and Watchel, P. (1984), "The Effects of Inflation and Money Supply Announcements on Interest Rates," Journal of Finance, 39, 1177-1188. 


\section{Table 1: Sample Statistics}

\begin{tabular}{|c|c|c|c|c|c|c|c|c|}
\hline & & Mean & Std. & Skew & Kurt. & $\rho_{1}$ & $\rho_{2}$ & $\rho_{3}$ \\
\hline \multicolumn{9}{|l|}{ Returns } \\
\hline & $\Delta p_{t}$ & -0.009 & 0.544 & 0.149 & 4.691 & $\begin{array}{l}-0.022 \\
(0.448)\end{array}$ & $\begin{array}{c}0.003 \\
(0.918) \\
\end{array}$ & $\begin{array}{l}-0.011 \\
(0.658)\end{array}$ \\
\hline \multicolumn{9}{|c|}{$\underline{\text { Order Flows }}$} \\
\hline \multicolumn{9}{|c|}{ Corporations } \\
\hline US & $\Delta x_{t}^{C}$ & -3.424 & 45.555 & -1.650 & 19.692 & $\begin{array}{c}0.075 \\
(0.018)\end{array}$ & $\begin{array}{c}0.053 \\
(0.060)\end{array}$ & $\begin{array}{l}-0.035 \\
(0.255)\end{array}$ \\
\hline Non-US & $\Delta x_{t}^{C^{*}}$ & -11.879 & 81.666 & 0.573 & 11.440 & $\begin{array}{c}0.033 \\
(0.192)\end{array}$ & $\begin{array}{c}0.045 \\
(0.091)\end{array}$ & $\begin{array}{c}0.028 \\
(0.286)\end{array}$ \\
\hline \multicolumn{9}{|l|}{ Traders } \\
\hline US & $\Delta x_{t}^{T}$ & -0.783 & 138.745 & 0.502 & 15.426 & $\begin{array}{c}0.114 \\
(0.003)\end{array}$ & $\begin{array}{c}0.046 \\
(0.076)\end{array}$ & $\begin{array}{c}0.001 \\
(0.967)\end{array}$ \\
\hline Non-US & $\Delta x_{t}^{T^{*}}$ & 2.257 & 82.462 & 0.400 & 7.598 & $\begin{array}{l}-0.025 \\
(0.506)\end{array}$ & $\begin{array}{l}-0.023 \\
(0.397)\end{array}$ & $\begin{array}{l}-0.029 \\
(0.212)\end{array}$ \\
\hline \multicolumn{9}{|c|}{ Investors } \\
\hline US & $\Delta x_{t}^{I}$ & 3.821 & 59.977 & -1.946 & 33.632 & $\begin{array}{c}0.063 \\
(0.048)\end{array}$ & $\begin{array}{c}0.023 \\
(0.437)\end{array}$ & $\begin{array}{c}0.031 \\
(0.188)\end{array}$ \\
\hline Non-US & $\Delta x_{t}^{I^{*}}$ & 3.170 & 112.391 & 2.472 & 40.441 & $\begin{array}{c}0.068 \\
(0.003)\end{array}$ & $\begin{array}{c}0.038 \\
(0.070)\end{array}$ & $\begin{array}{c}0.027 \\
(0.175)\end{array}$ \\
\hline \multicolumn{9}{|c|}{ Aggregate } \\
\hline & $\Delta x_{t}$ & -4.940 & 226.073 & 0.677 & 9.418 & $\begin{array}{c}0.098 \\
(0.001)\end{array}$ & $\begin{array}{c}0.059 \\
(0.016)\end{array}$ & $\begin{array}{c}0.026 \\
(0.310)\end{array}$ \\
\hline \multicolumn{9}{|c|}{ Correlation Matrix } \\
\hline & $\Delta p_{t}$ & $\Delta x_{t}^{C}$ & $\Delta x_{t}^{C^{*}}$ & $\Delta x_{+}^{T}$ & $\Delta x_{t}^{T^{*}}$ & $\Delta x_{t}^{I}$ & $\Delta x_{t}^{I^{*}}$ & $\Delta x_{t}$ \\
\hline$\Delta p_{t}$ & 1.000 & & & & & & & \\
\hline$\Delta x_{t}^{C}$ & -0.034 & 1.000 & & & & & & \\
\hline$\Delta x_{t}^{C^{*}}$ & -0.102 & 0.020 & 1.000 & & & & & \\
\hline$\Delta x_{t}^{T}$ & 0.131 & 0.033 & -0.048 & 1.000 & & & & \\
\hline$\Delta x_{t}^{T^{*}}$ & 0.102 & -0.014 & -0.038 & -0.012 & 1.000 & & & \\
\hline$\Delta x_{t}^{I}$ & 0.070 & -0.031 & 0.014 & -0.063 & 0.021 & 1.000 & & \\
\hline$\Delta x_{t}^{I^{*}}$ & 0.192 & -0.013 & -0.022 & 0.038 & -0.011 & 0.067 & 1.000 & \\
\hline$\Delta x_{t}$ & 0.178 & 0.209 & 0.319 & 0.601 & 0.339 & 0.265 & 0.521 & 1.000 \\
\hline
\end{tabular}

Notes: Exchange rate returns, $\Delta p_{t}$, are calculated as the daily change in the natural log of the spot price $(\$ / €) \times 100, \Delta x_{t}^{j}$ denotes order flow for Euros by segment $j$ in $\$ \mathrm{~m}$. The statistics reported below $\rho_{i}$ are the sample autocorrelations at lag $i$. P-values for the null hypothesis of no autocorrelation are reported in parenthesis. The sample spans the period 4/11/93 - 6/30/99, and includes observations on 1682 trading days. 
Table 2: Impact of US Announcements

\begin{tabular}{|c|c|c|c|c|c|c|c|c|c|}
\hline \multirow{2}{*}{\multicolumn{3}{|c|}{ Announcements }} & \multirow{3}{*}{$\begin{array}{c}\text { Returns } \\
\Delta p_{t}\end{array}$} & \multicolumn{6}{|c|}{ Order Flows } \\
\hline & & & & \multicolumn{2}{|c|}{ Corporations } & \multicolumn{2}{|c|}{ Traders } & \multicolumn{2}{|c|}{ Investors } \\
\hline \# & Item & $\# \mathrm{~N}$ & & $\mathrm{US}: \Delta x_{t}^{C}$ & $\begin{array}{l}\text { Non-US } \\
: \Delta x_{t}^{C^{*}}\end{array}$ & $\mathrm{US}: \Delta x_{t}^{T}$ & $\begin{array}{c}\text { Non- } \\
\text { US: } \Delta x_{t}^{T^{*}}\end{array}$ & $\mathrm{US}: \Delta x_{t}^{I^{*}}$ & $\begin{array}{l}\text { Non-US: } \\
\Delta x_{t}^{I^{*}}\end{array}$ \\
\hline 1 & Bus Inv & 63 & 0.016 & -4.042 & 0.271 & 10.989 & -1.062 & -4.045 & 8.186 \\
\hline 2 & Capacity & 70 & 0.036 & -2.723 & -1.303 & $-67.202 * * *$ & -4.417 & 1.149 & -14.498 \\
\hline 3 & Claims & 323 & $0.051 * *$ & -1.049 & -5.236 & $-11.165^{*}$ & -0.775 & -2.094 & 3.681 \\
\hline 4 & Confidence & 78 & $-0.085 * *$ & -0.777 & -7.642 & 2.810 & 1.753 & -1.614 & 0.803 \\
\hline 5 & Construction & 76 & 0.060 & -0.475 & 10.610 & -6.777 & 4.347 & -4.308 & 2.162 \\
\hline 6 & CPI & 48 & 0.043 & $-10.035^{* * *}$ & -6.383 & 0.667 & $-9.309 * *$ & 5.398 & $17.916^{* *}$ \\
\hline 7 & Credit & 77 & -0.006 & -4.457 & $15.969 * *$ & -10.685 & 1.457 & 20.252 & -1.999 \\
\hline 8 & Durables & 76 & -0.014 & -0.885 & $16.545^{* *}$ & 6.686 & -7.598 & 1.100 & -6.101 \\
\hline 9 & Fact. Ords & 72 & 0.073 & 1.837 & 7.698 & $28.464 * * *$ & 3.883 & -0.070 & 0.270 \\
\hline 10 & Fed Funds & 19 & -0.011 & -1.461 & -1.330 & -7.115 & $8.847 * * *$ & -8.781 & -12.561 \\
\hline 11 & GDP adv & 25 & -0.071 & 1.388 & -7.685 & 7.797 & -8.875 & 2.286 & 10.977 \\
\hline 12 & GDP fin & 25 & 0.169 & -6.919 & -6.840 & $-75.010 * *$ & -12.677 & $18.697 * * *$ & -11.245 \\
\hline 13 & GDP prl & 24 & -0.127 & $6.351 *$ & -11.865 & -8.439 & $29.183 * *$ & 12.131 & 1.870 \\
\hline 14 & Earnings & 64 & -0.015 & 1.336 & -7.127 & $-20.734 *$ & -6.282 & $15.408^{*}$ & $10.414 *$ \\
\hline 15 & House Sts & 71 & -0.028 & $-11.642 * *$ & -2.582 & -12.359 & 1.468 & 4.275 & 1.715 \\
\hline 16 & Ind. Prod & 62 & -0.090 & 9.369 & 6.467 & $47.809 *$ & 2.373 & 2.573 & 14.277 \\
\hline 17 & Leading & 54 & -0.062 & -5.793 & $16.126^{* * *}$ & 3.724 & 8.194 & $-16.071 * *$ & -9.011 \\
\hline 18 & M1 & 77 & $0.105^{*}$ & -3.191 & -4.617 & 35.457 & -12.339 & -14.217 & 8.913 \\
\hline 19 & M2 & 73 & -0.070 & 9.269 & 0.838 & -34.419 & 3.883 & -2.360 & 6.365 \\
\hline 20 & M3 & 68 & 0.061 & 3.874 & 3.842 & -5.395 & $-11.706^{*}$ & -6.976 & 3.588 \\
\hline 21 & NAPM & 76 & $-0.107 * *$ & -0.314 & 15.150 & -1.577 & -1.962 & 2.219 & -18.114 \\
\hline 22 & New Homes & 77 & $-0.139 * *$ & $9.687 * *$ & 10.638 & -2.769 & $-11.462 *$ & -12.283 & -1.983 \\
\hline 23 & NF Empl. & 78 & $-0.239 * * *$ & -0.646 & 4.261 & $-28.877 * *$ & 5.736 & 2.248 & -6.596 \\
\hline 24 & Cons. & 60 & $-0.118^{* *}$ & $-4.062 *$ & -6.485 & 14.165 & 4.869 & $-17.800 * *$ & 10.130 \\
\hline 25 & Income & 63 & -0.102 & 1.330 & -9.416 & -10.518 & 7.269 & 9.718 & -1.901 \\
\hline 26 & PPI & 66 & $-0.084 * *$ & -9.191 & -6.970 & 24.842 & -5.439 & 3.416 & -6.401 \\
\hline 27 & Ret. Sales & 70 & -0.018 & 2.030 & -1.992 & -10.506 & -2.393 & 1.377 & -9.336 \\
\hline 28 & Budget & 75 & 0.029 & $5.729 *$ & 4.206 & -1.191 & 1.526 & -5.014 & -12.114 \\
\hline 29 & Trade Bal. & 77 & $-0.117 * * *$ & 0.641 & 16.961 & -6.227 & 1.576 & 3.187 & $-19.474 *$ \\
\hline 30 & Unemploy. & 56 & $0.098 *$ & 7.877 & -1.578 & $-21.174 *$ & 8.459 & -9.400 & -5.811 \\
\hline
\end{tabular}




\section{Table 2 (Cont.) : Impact of German Announcements}

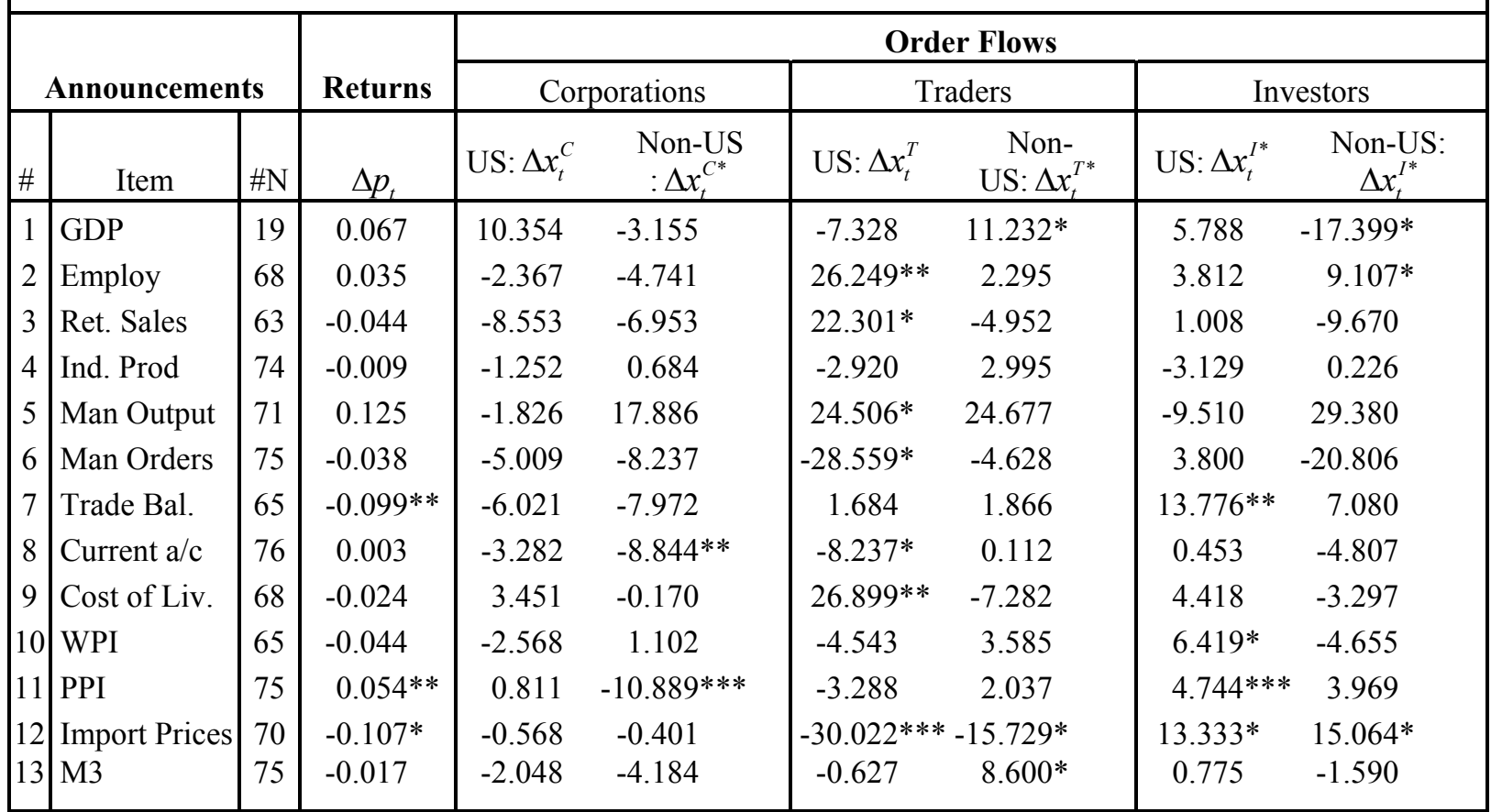

Notes: Each column reports the estimated coefficients from the regression of the VAR innovation listed at the head of the column on the 43 announcements shown on the left. Innovations are computed from a $2^{\text {nd }}$. order VAR for returns and the six order flow segments estimated in daily data over 1682 trading days. \#N denotes the number of each news announcements in the sample. All announcements are standardized to have a unit variance over the sample period. "*”, "**" and “***" denote statistical significance at the $10 \%, 5 \%$, and $1 \%$ level respectively. 


\begin{tabular}{|c|c|c|c|c|c|c|c|c|}
\hline \multicolumn{9}{|c|}{ Table 3: Order Flow Dynamics } \\
\hline \multicolumn{2}{|r|}{ US News } & \multirow{2}{*}{$\begin{array}{c}\text { Order Flow } \\
\text { Segment }\end{array}$} & \multicolumn{6}{|c|}{ Days After Announcement } \\
\hline$\nexists$ & \# Item & & 0 & 1 & 2 & 3 & 4 & $1-4$ \\
\hline \multicolumn{2}{|c|}{$2 \quad$ Capacity } & $\Delta x_{t}^{T}$ & -34.522 & $\begin{array}{l}-3.629 \\
(0.000)\end{array}$ & $\begin{array}{l}-1.939 \\
(0.009)\end{array}$ & $\begin{array}{l}-0.537 \\
(0.002)\end{array}$ & $\begin{array}{l}-0.226 \\
(0.052)\end{array}$ & $\begin{array}{l}-6.331 \\
(0.000)\end{array}$ \\
\hline \multicolumn{2}{|c|}{$6 \quad$ CPI } & $\Delta x_{t}^{C}$ & -8.775 & $\begin{array}{l}-0.538 \\
(0.010)\end{array}$ & $\begin{array}{l}-0.922 \\
(0.000)\end{array}$ & $\begin{array}{l}-0.098 \\
(0.011)\end{array}$ & $\begin{array}{l}-0.045 \\
(0.096)\end{array}$ & $\begin{array}{l}-1.602 \\
(0.000)\end{array}$ \\
\hline 7 & Credit & $\Delta x_{t}^{C^{*}}$ & 15.601 & $\begin{array}{c}1.074 \\
(0.014)\end{array}$ & $\begin{array}{l}1.335 \\
(0.001)\end{array}$ & $\begin{array}{c}0.219 \\
(0.002)\end{array}$ & $\begin{array}{c}0.113 \\
(0.025)\end{array}$ & $\begin{array}{c}2.741 \\
(0.000)\end{array}$ \\
\hline 8 & Durables & $\Delta x_{t}^{C^{*}}$ & 14.962 & $\begin{array}{c}0.687 \\
(0.054)\end{array}$ & $\begin{array}{l}1.148 \\
(0.002)\end{array}$ & $\begin{array}{c}0.144 \\
(0.019)\end{array}$ & $\begin{array}{c}0.075 \\
(0.061)\end{array}$ & $\begin{array}{c}2.055 \\
(0.001)\end{array}$ \\
\hline 9 & Fact. Ords & $\Delta x_{t}^{T}$ & 28.732 & $\begin{array}{c}3.543 \\
(0.000)\end{array}$ & $\begin{array}{l}1.001 \\
(0.128)\end{array}$ & $\begin{array}{c}0.312 \\
(0.035)\end{array}$ & $\begin{array}{c}0.189 \\
(0.134)\end{array}$ & $\begin{array}{c}5.045 \\
(0.005)\end{array}$ \\
\hline 10 & Fed Funds & $\Delta x_{t}^{T^{*}}$ & 8.958 & $\begin{array}{l}-0.557 \\
(0.083)\end{array}$ & $\begin{array}{l}-0.022 \\
(0.794)\end{array}$ & $\begin{array}{l}-0.003 \\
(0.809)\end{array}$ & $\begin{array}{c}0.025 \\
(0.205)\end{array}$ & $\begin{array}{l}-0.556 \\
(0.044)\end{array}$ \\
\hline 12 & GDP fin. & $\Delta x_{t}^{I}$ & 18.488 & $\begin{array}{l}1.205 \\
(0.132)\end{array}$ & $\begin{array}{l}-1.555 \\
(0.029)\end{array}$ & $\begin{array}{c}0.086 \\
(0.295)\end{array}$ & $\begin{array}{c}0.179 \\
(0.012)\end{array}$ & $\begin{array}{l}-0.085 \\
(0.720)\end{array}$ \\
\hline 13 & GDP prl. & $\Delta x_{t}^{T^{*}}$ & 29.868 & $\begin{array}{c}0.710 \\
(0.273)\end{array}$ & $\begin{array}{l}-0.898 \\
(0.111)\end{array}$ & $\begin{array}{c}0.077 \\
(0.279)\end{array}$ & $\begin{array}{c}0.083 \\
(0.154)\end{array}$ & $\begin{array}{l}-0.028 \\
(0.893)\end{array}$ \\
\hline 17 & Leading & $\Delta x_{t}^{C^{*}}$ & 15.817 & $\begin{array}{l}1.556 \\
(0.006)\end{array}$ & $\begin{array}{c}0.286 \\
(0.200)\end{array}$ & $\begin{array}{c}0.102 \\
(0.076)\end{array}$ & $\begin{array}{c}0.061 \\
(0.136)\end{array}$ & $\begin{array}{c}2.005 \\
(0.007)\end{array}$ \\
\hline 23 & Non F Empl. & $\Delta x_{t}^{T}$ & -25.998 & $\begin{array}{l}-3.094 \\
(0.000)\end{array}$ & $\begin{array}{l}-3.778 \\
(0.000)\end{array}$ & $\begin{array}{l}-0.732 \\
(0.001)\end{array}$ & $\begin{array}{l}-0.555 \\
(0.001)\end{array}$ & $\begin{array}{l}-8.158 \\
(0.000)\end{array}$ \\
\hline 24 & Consumption & $\Delta x_{t}^{I}$ & -17.979 & $\begin{array}{l}-1.086 \\
(0.030)\end{array}$ & $\begin{array}{c}1.086 \\
(0.013)\end{array}$ & $\begin{array}{c}0.005 \\
(0.846)\end{array}$ & $\begin{array}{l}-0.022 \\
(0.313)\end{array}$ & $\begin{array}{l}-0.018 \\
(0.878)\end{array}$ \\
\hline \multirow[t]{3}{*}{30} & Unemploy. & $\Delta x_{t}^{C}$ & 7.806 & $\begin{array}{c}0.378 \\
(0.035) \\
\end{array}$ & $\begin{array}{c}0.962 \\
(0.000) \\
\end{array}$ & $\begin{array}{c}0.079 \\
(0.021) \\
\end{array}$ & $\begin{array}{c}0.097 \\
(0.005) \\
\end{array}$ & $\begin{array}{c}1.516 \\
(0.000) \\
\end{array}$ \\
\hline & \multirow{2}{*}{ German News } & \multirow{2}{*}{$\begin{array}{c}\text { Order Flow } \\
\text { Segment }\end{array}$} & \multicolumn{6}{|c|}{ Days After Announcement } \\
\hline & & & 0 & 1 & 2 & 3 & 4 & $1-4$ \\
\hline \multicolumn{2}{|c|}{$2 \quad$ Employ } & $\Delta x_{t}^{T}$ & 26.097 & $\begin{array}{c}2.924 \\
(0.000)\end{array}$ & $\begin{array}{l}1.956 \\
(0.010)\end{array}$ & $\begin{array}{c}0.531 \\
(0.001)\end{array}$ & $\begin{array}{c}0.205 \\
(0.073)\end{array}$ & $\begin{array}{c}5.616 \\
(0.001)\end{array}$ \\
\hline 3 & Ret. Sales & $\Delta x_{t}^{C}$ & -9.304 & $\begin{array}{l}-0.189 \\
(0.139)\end{array}$ & $\begin{array}{l}-0.523 \\
(0.010)\end{array}$ & $\begin{array}{l}-0.031 \\
(0.180)\end{array}$ & $\begin{array}{l}-0.039 \\
(0.084)\end{array}$ & $\begin{array}{l}-0.782 \\
(0.007)\end{array}$ \\
\hline 8 & Current a/c & $\Delta x_{t}^{C^{*}}$ & -8.790 & $\begin{array}{l}-0.123 \\
(0.302)\end{array}$ & $\begin{array}{l}-0.521 \\
(0.002)\end{array}$ & $\begin{array}{l}-0.018 \\
(0.267)\end{array}$ & $\begin{array}{l}-0.036 \\
(0.077)\end{array}$ & $\begin{array}{l}-0.698 \\
(0.014)\end{array}$ \\
\hline 9 & Cost of Liv. & $\Delta x_{t}^{T}$ & 27.454 & $\begin{array}{c}3.457 \\
(0.000)\end{array}$ & $\begin{array}{c}0.368 \\
(0.379)\end{array}$ & $\begin{array}{c}0.287 \\
(0.026)\end{array}$ & $\begin{array}{c}0.039 \\
(0.591)\end{array}$ & $\begin{array}{c}4.152 \\
(0.005)\end{array}$ \\
\hline & PPI & $\Delta x_{t}^{C^{*}}$ & -10.745 & $\begin{array}{l}-0.696 \\
(0.003)\end{array}$ & $\begin{array}{l}-0.640 \\
(0.001)\end{array}$ & $\begin{array}{l}-0.089 \\
(0.008)\end{array}$ & $\begin{array}{l}-0.051 \\
(0.023)\end{array}$ & $\begin{array}{l}-1.476 \\
(0.000)\end{array}$ \\
\hline & Import Prices & $\Delta x_{t}^{T}$ & -31.306 & $\begin{array}{l}-4.654 \\
(0.000)\end{array}$ & $\begin{array}{l}-1.728 \\
(0.014)\end{array}$ & $\begin{array}{l}-0.524 \\
(0.005)\end{array}$ & $\begin{array}{l}-0.394 \\
(0.006)\end{array}$ & $\begin{array}{l}-7.300 \\
(0.000)\end{array}$ \\
\hline & $\begin{array}{l}\text { nulation) for the } \\
\text { der flow segmen } \\
\text { ders } \Delta x_{t}^{T^{*}} \text {, US it }\end{array}$ & $\begin{array}{l}\text { ll hypoth } \\
\text { are: US } \\
\text { stors } \Delta x \\
\end{array}$ & that $f$ & $\begin{array}{l}\Delta x_{t}^{C}, \mathrm{r} \\
\text { investo }\end{array}$ & $\begin{array}{l}\text { IS } j \text { (i.e } \\
I^{*}\end{array}$ & no direc & $\begin{array}{l}\text { act on } \\
\text { S trader }\end{array}$ & $\begin{array}{l}\text { flow). } \\
t \text {, non }\end{array}$ \\
\hline
\end{tabular}




\begin{tabular}{|c|c|c|c|c|c|c|c|}
\hline \multicolumn{8}{|c|}{$\begin{array}{l}\text { Table 4: Contribution of Announcements to } \\
\text { Order Flow Variance }\end{array}$} \\
\hline \multicolumn{2}{|r|}{ US News } & \multirow{2}{*}{$\begin{array}{c}\text { Order Flow } \\
\text { Segment }\end{array}$} & \multicolumn{5}{|c|}{ Days After Announcement } \\
\hline \# & Item & & \begin{tabular}{l|l|l|}
0 \\
\end{tabular} & \begin{tabular}{l|l}
1 & \\
\end{tabular} & \begin{tabular}{l|l}
2 & \\
\end{tabular} & 3 & 4 \\
\hline 2 & Capacity & $\Delta x_{t}^{T}$ & 6.357 & 2.27 & 3.045 & 2.417 & 3.438 \\
\hline 6 & CPI & $\Delta x_{t}^{C}$ & 3.769 & 3.878 & 1.612 & 1.225 & 0.868 \\
\hline 7 & Credit & $\Delta x_{t}^{C^{*}}$ & 3.608 & 4.626 & 5.778 & 6.217 & 7.038 \\
\hline 8 & Durables & $\Delta x_{t}^{C^{*}}$ & 3.319 & 3.421 & 2.523 & 2.745 & 2.930 \\
\hline 9 & Fact. Orders & $\Delta x_{t}^{T}$ & 4.403 & 0.606 & 1.026 & 1.684 & 1.090 \\
\hline 10 & Fed Funds & $\Delta x_{t}^{T^{*}}$ & 1.184 & 0.004 & 0.012 & 1.032 & 0.071 \\
\hline 12 & GDP fin. & $\Delta x_{t}^{I}$ & 9.718 & 6.908 & 0.765 & 10.451 & 0.148 \\
\hline 13 & GDP prl. & $\Delta x_{t}^{T^{*}}$ & 13.159 & 6.556 & 9.173 & 10.996 & 12.628 \\
\hline 17 & Leading & $\Delta x_{t}^{C^{*}}$ & 3.709 & 0.212 & 1.262 & 1.789 & 1.358 \\
\hline 23 & Non Farm Empl. & $\Delta x_{t}^{T}$ & 3.605 & 8.617 & 5.659 & 14.532 & 6.214 \\
\hline 24 & Cons. & $\Delta x_{t}^{I}$ & 9.189 & 3.369 & 0.003 & 0.157 & 0.116 \\
\hline 30 & Unemployment & $\Delta x_{t}^{C}$ & 2.982 & 4.222 & 1.057 & 5.827 & 2.063 \\
\hline & German News & Order Flow & & Days A & Announc & ent & \\
\hline$\#$ & Item & Segment & 0 & \begin{tabular}{l|l}
1 &
\end{tabular} & \begin{tabular}{l|l}
2 &
\end{tabular} & 3 & 4 \\
\hline 2 & Employment & $\Delta x_{t}^{T}$ & 3.633 & 2.310 & 2.981 & 1.990 & 2.703 \\
\hline 3 & Ret. Sales & $\Delta x_{t}^{C}$ & 4.237 & 1.247 & 0.158 & 0.946 & 0.158 \\
\hline 8 & Current $\mathrm{A} / \mathrm{Cc}$ & $\Delta x_{t}^{C^{*}}$ & 1.146 & 0.704 & 0.037 & 0.631 & 0.070 \\
\hline 9 & Cost of Living. & $\Delta x_{t}^{T}$ & 4.02 & 0.082 & 0.873 & 0.073 & 0.540 \\
\hline 11 & PPI & $\Delta x_{t}^{C^{*}}$ & 1.711 & 1.063 & 0.953 & 1.264 & 1.162 \\
\hline 12 & Import Prices & $\Delta x_{t}^{T}$ & 5.228 & 1.804 & 2.898 & 7.318 & 5.314 \\
\hline
\end{tabular}




\begin{tabular}{|c|c|c|c|c|c|c|}
\hline \multicolumn{7}{|c|}{ Table 5: Return Dynamics Induced By Announcements } \\
\hline \multicolumn{2}{|c|}{ US News } & \multicolumn{5}{|c|}{ Days After Announcement } \\
\hline Item \# & Item & 1 & 2 & 3 & 4 & 1 to 4 \\
\hline \multicolumn{2}{|c|}{3 Claims } & $\begin{array}{r}-17.483 \\
(0.000)\end{array}$ & $\begin{array}{l}-5.104 \\
(0.020)\end{array}$ & $\begin{array}{l}-0.175 \\
(0.395)\end{array}$ & $\begin{array}{c}0.632 \\
(0.101)\end{array}$ & $\begin{array}{r}-22.130 \\
(0.000)\end{array}$ \\
\hline 4 & Confidence & $\begin{array}{l}-5.082 \\
(0.173)\end{array}$ & $\begin{array}{l}-2.849 \\
(0.140)\end{array}$ & $\begin{array}{l}-0.615 \\
(0.157)\end{array}$ & $\begin{array}{c}0.242 \\
(0.457)\end{array}$ & $\begin{array}{l}-8.304 \\
(0.083)\end{array}$ \\
\hline 21 & NAPM & $\begin{array}{l}-2.932 \\
(0.201)\end{array}$ & $\begin{array}{c}2.521 \\
(0.079)\end{array}$ & $\begin{array}{c}1.139 \\
(0.005)\end{array}$ & $\begin{array}{c}0.889 \\
(0.028)\end{array}$ & $\begin{array}{c}1.618 \\
(0.394)\end{array}$ \\
\hline 22 & New Homes & $\begin{array}{c}2.151 \\
(0.248)\end{array}$ & $\begin{array}{l}-1.453 \\
(0.161)\end{array}$ & $\begin{array}{c}0.322 \\
(0.139)\end{array}$ & $\begin{array}{c}0.252 \\
(0.245)\end{array}$ & $\begin{array}{c}1.272 \\
(0.437)\end{array}$ \\
\hline 23 & Non Farm Empl. & $\begin{array}{l}-1.769 \\
(0.098)\end{array}$ & $\begin{array}{c}2.031 \\
(0.012)\end{array}$ & $\begin{array}{c}0.347 \\
(0.015)\end{array}$ & $\begin{array}{c}0.567 \\
(0.001)\end{array}$ & $\begin{array}{c}1.176 \\
(0.235)\end{array}$ \\
\hline 24 & Cons & $\begin{array}{l}-2.264 \\
(0.291)\end{array}$ & $\begin{array}{l}-9.458 \\
(0.000)\end{array}$ & $\begin{array}{l}-0.972 \\
(0.017)\end{array}$ & $\begin{array}{l}-0.015 \\
(0.903)\end{array}$ & $\begin{array}{r}-12.709 \\
(0.002)\end{array}$ \\
\hline 26 & PPI & $\begin{array}{r}-16.992 \\
(0.000)\end{array}$ & $\begin{array}{l}-6.518 \\
(0.010)\end{array}$ & $\begin{array}{l}-0.726 \\
(0.088)\end{array}$ & $\begin{array}{c}0.533 \\
(0.168)\end{array}$ & $\begin{array}{r}-23.704 \\
(0.000)\end{array}$ \\
\hline 29 & Trade Bal & $\begin{array}{l}-3.089 \\
(0.173) \\
\end{array}$ & $\begin{array}{c}3.167 \\
(0.032) \\
\end{array}$ & $\begin{array}{c}1.098 \\
(0.009) \\
\end{array}$ & $\begin{array}{c}0.888 \\
(0.019) \\
\end{array}$ & $\begin{array}{c}2.064 \\
(0.323) \\
\end{array}$ \\
\hline \multicolumn{2}{|c|}{ German News } & \multicolumn{5}{|c|}{ Days After Announcement } \\
\hline Item \# & Item & 1 & 2 & 3 & 4 & 1 to 4 \\
\hline \multicolumn{2}{|c|}{$7 \quad$ Trade Bal } & $\begin{array}{r}-11.630 \\
(0.006)\end{array}$ & $\begin{array}{c}2.965 \\
(0.083)\end{array}$ & $\begin{array}{l}-0.344 \\
(0.232)\end{array}$ & $\begin{array}{c}0.600 \\
(0.120)\end{array}$ & $\begin{array}{l}-8.409 \\
(0.047)\end{array}$ \\
\hline 11 & PPI & $\begin{array}{l}-0.920 \\
(0.580) \\
\end{array}$ & $\begin{array}{l}-2.288 \\
(0.098) \\
\end{array}$ & $\begin{array}{c}0.889 \\
(0.020) \\
\end{array}$ & $\begin{array}{c}0.640 \\
(0.065) \\
\end{array}$ & $\begin{array}{l}-1.680 \\
(0.416)\end{array}$ \\
\hline $\begin{array}{l}\text { Notes: } \\
\text { price in } \\
\text { estimate } \\
\text { that } \beta_{i}^{j} \\
\text { price im }\end{array}$ & $\begin{array}{l}\text { The table reports t } \\
\text { npact is report as } \\
\text { ed price impact we } \\
=0 \text { for all } i \text { and } j \\
\text { apacts that are stati }\end{array}$ & $\begin{array}{l}\text { pact on ret } \\
\text { centage of } \\
\mathrm{rt} \text { the p-va } \\
\text { eight US }\end{array}$ & $\begin{array}{l}p_{t} \text { on days } \\
\text { rice impac } \\
\text { omputed by } \\
\text { ncements } \\
\text { he } 5 \% \text { lev }\end{array}$ & $\begin{array}{l}4 \text { followi } \\
\text { he day of } \\
\text { te Carlo s } \\
\text { vo Germa } \\
\text { eported in }\end{array}$ & $\begin{array}{l}\text { news an } \\
\text { inouncem } \\
\text { ion) for } t \\
\text { uncement }\end{array}$ & $\begin{array}{l}\text { cement. Th } \\
\text { Below eac } \\
1 \text { hypothesi } \\
\text { e immediat }\end{array}$ \\
\hline
\end{tabular}




\section{Table 6: Contribution of Announcements to Return Variance}

\begin{tabular}{|c|c|c|c|c|c|}
\hline US News & \multicolumn{5}{|c|}{ Days After Announcement } \\
\hline \# Item & 0 & 1 & 2 & 3 & 4 \\
\hline 3 Claims & 0.723 & 0.377 & 0.018 & 0.714 & 0.034 \\
\hline 4 Confidence & 2.532 & 0.412 & 0.767 & 0.367 & 0.054 \\
\hline 21 NAPM & 3.952 & 0.503 & 4.105 & 7.732 & 6.027 \\
\hline 22 New Homes & 6.453 & 0.273 & 0.536 & 1.011 & 1.549 \\
\hline 23 Non F Empl. & 26.479 & 2.189 & 2.55 & 21.091 & 10.174 \\
\hline 24 Consumption & 4.203 & 7.534 & 3.177 & 0.002 & 1.304 \\
\hline 26 PPI & 2.199 & 1.872 & 0.929 & 1.545 & 0.027 \\
\hline 29 Trade Balance & 4.573 & 0.919 & 4.413 & 8.913 & 6.511 \\
\hline German News & \multicolumn{5}{|c|}{ Days After Announcement } \\
\hline \# Item & 0 & 1 & 2 & 3 & 4 \\
\hline 7 Trade Balance & 3.276 & 0.577 & 0.309 & 2.918 & 0.184 \\
\hline 11 PPI & 1.047 & 0.11 & 0.662 & 1.06 & 0.914 \\
\hline
\end{tabular}

Notes: The table reports the variance of daily exchange rate returns due to the announcement (listed in the right hand column) as a percentage of the variance due to all shocks. 
Figure 1: Order Flow Segments (cumulative \$bn)

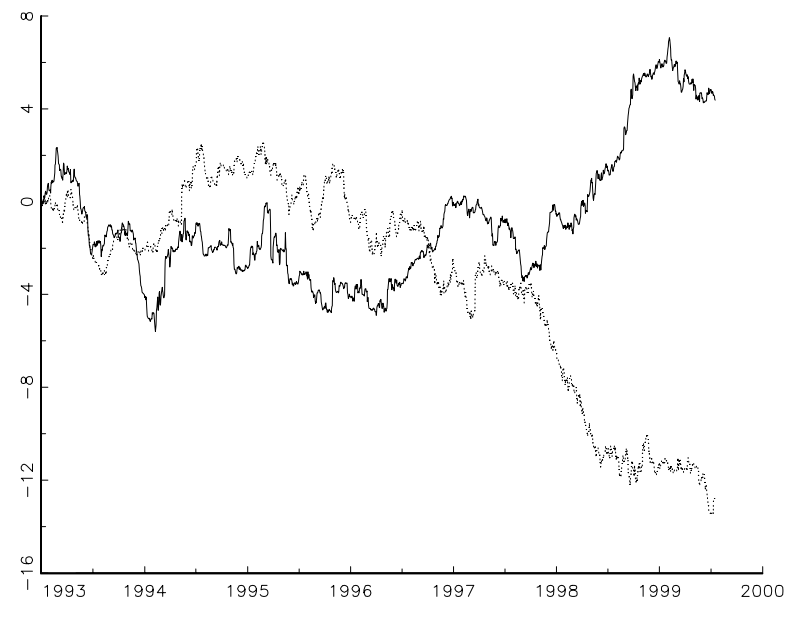

A: Aggregates: US = solid, non-US = dashed.

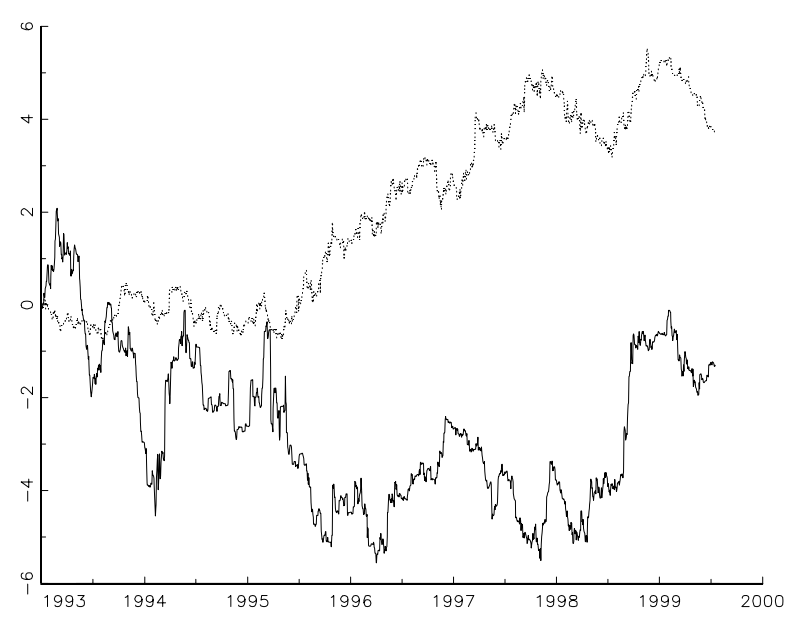

C: Traders: US $=$ solid, non-US $=$ dashed

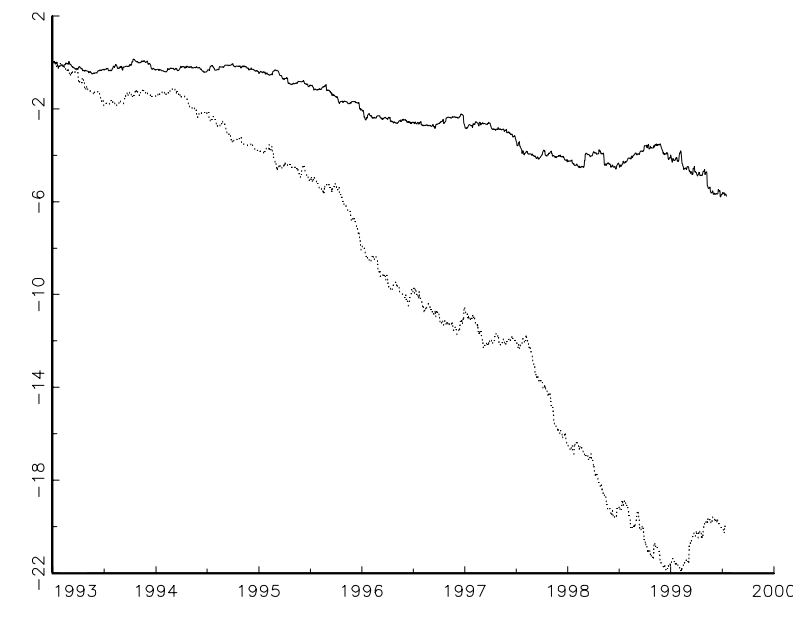

B: Corporations: US $=$ solid, non-US $=$ dashed

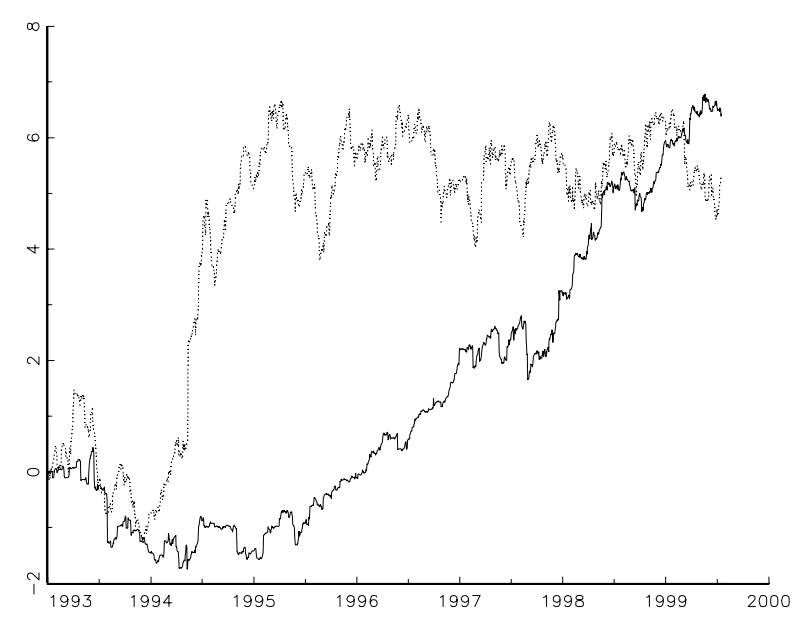

D: Investors: US $=$ solid, non-US $=$ dashed 